J. Product. \& Dev., 12(1): 101-114 (2007)

\title{
EFFECT OF IRRIGATION FREQUENCY AND NITROGEN LEVELS ON GROWTH, MINERAL COMPOSITION AND PRODUCTIVITY OF BROAD BEAN (Vicia faba L.)
}

\author{
El-S. L. El-S. Fathy, *; M.M. El-Hamady**and El-Said,M. El-Said* \\ Vegetable Department, Hort. Research Institute, Agriculture Research Center, Cairo, \\ Egypt. \\ **Plant Production Department., Efficient Productivity Institute., Zagazig \\ University, Egypt.
}

\begin{abstract}
Two field experiments, were conducted during 2002/2003, 2003/2004 at Awish El-Hagar village, Mansoura city, Dakahlia Governorate to study the effect of irrigation frequency (one, two and three irrigations besides to sowing irrigation), nitrogen fertilization $(0,25$ and $50 \mathrm{~kg} \mathrm{~N} / \mathrm{fed}$.) and their interaction on growth, mineral composition, yield and its components of broad bean (Vicia faba L.) plants.

The results summarized as follows :

(1) Increasing watering number from one to three resulted in significant responses and increments in all growth characters, $N, P$ and $K$ concentration of leaves, number of pods /plant, pod diameter, pod yield / plant and total yield/fed. of broad bean plants during the two seasons.

There was no satisfactory differences in pod yields between two and three irrigation treatments.

(2) Increasing $N$ rate from 0 up to $50 \mathrm{~kg} N / f e d$. significantly increased tillering, and dry matter accumulation potential, also mineral concentration, pod yield and its components in the two seasons. The results prove also, the importance of $N$ fertilization and insufficienty of the fixed nitrogen for optimum performances and maximum yield for broad bean.

(3) In similar trend, the interaction gave significant effects on the whole performances of broad bean plants, during both seasons.

The present study concluded that, for obtaining the best growth, mineral concentration and maximum productivity of broad bean crop, it could be fertilized with nitrogen $50 \mathrm{~kg} \mathrm{~N} / f e d$. and irrigated two times (just before the beginning of flowering and at the beginning of pod formation) after sowing irrigation.
\end{abstract}

Keywords: Irrigation frequency, nitrogen levels, growth, mineral composition, productivity, broad bean (Vicia faba l.)

\section{INTRODUCTION}

Broad bean (Vicia faba L.) is an important legume vegetable, regarded as a rich and sheep protein source. It is agronomically, differed greatly from field bean. 
Since it had high growth and productivity potential as well as multiplying harvesting nature.

In practic many growers wrongly give less attention for $\mathrm{N}$ fertilization and irrigation frequency of broad bean plants as they doing with faba bean plants.

It was know that broad bean (Vicia faba L.) plants has a shollow root system with little osmoregulation capacity and very sensitive to water deficit/stress particularly during anthesis and pod filling (Bond et al., 1994).

There are differed, and contradected information in the published literature on the responses of faba bean plants to irrigation and $\mathrm{N}$ fertilization, and less is available for broad bean plants.

Also, it was found that water stress imposed at different developmental stages (pre- and post-flowering, pod formation for faba bean plants is greatly reduced their growth and productivity and that irrigation is greatly improved its different performances (Abd El-Haleem1994, Abo El-kheir et al., 2000, El-Tawill, 2003 and Allam, 2005).

On the other hand, $\mathrm{N}$ fertilization for maximum yield found to be ranged from applying small starter $\mathrm{N}$ dressing, (Papendick et al., 1988), to large ones (Bhan-Goo and Albritton, 1972 and Said et al.,1998). Consequently such crop need more attention for its right management including more and right $\mathrm{N}$ supplementation over its own potential for $\mathrm{N}$ fixation along with the right watering levels, all for maximizing its growth and productivity.

So the present work is designed for establishing right $\mathrm{N}$ fertilization and irrigation management for maximum productivity of broad bean plants.

\section{MATERIALS AND METHODS}

Two field experiments were conducted during 2002 / 2003 and 2003 / 2004 seasons at Awish El-Hagar village, Mansoura city, Dakahlia Governorate to study the effect of different nitrogen levels and irrigation frequency on growth, mineral composition and productivity of broad bean (Vicia faba L.) El-Kobrosy cv. The soil of the experimental field was clay loam in texture. The physical and chemical properties of the soil are shown in Table 1.

Seeds were sown and irrigated (sowing irrigation) on October 20 during the two successive seasons in plots of $14 \mathrm{~m}^{2}$ area with sowing density of 21700 plants / fed. All plots received calcium super phosphate and potassium sulphate 200 and 50 $\mathrm{kg} /$ fed., respectively, those were incorporated in to the soil before sowing. Also other cultural / practices were carried out as recommended.

Split plot experiments were designed, where main plots occupied with irrigation frequency treatments, one (before flowering), two (before flowering and at the beginning of pod formation ) and three (before flowering, at the beginning of pod formation and at the beginning of pod filling). Those in addition to planting irrigation, that applied for all plots. 
Table(1): Mechanical and chemical analysis of the experimental soil during two seasons.

\begin{tabular}{lcc}
\hline \multicolumn{1}{c}{ Soil properties } & $\mathbf{2 0 0 2}$ / $\mathbf{2 0 0 3}$ & $\mathbf{2 0 0 3 / 2 0 0 4}$ \\
\hline Clay \% & 43.00 & 44.7 \\
Silt \% & 32.90 & 31.00 \\
Sand \% & 24.10 & 24.30 \\
Texture & Clay loam & Clay loam \\
E.C. & 1.67 & 1.79 \\
Total N \% & 0.13 & 0.11 \\
Available P. (ppm). & 12.00 & 11.00 \\
Available K. $(\mathbf{p p m})$. & 402 & 397 \\
Available Ca. $(\mathbf{p p m})$. & 417 & 429 \\
pH & 7.75 & 7.81 \\
\hline
\end{tabular}

While, sub plots received different $\mathrm{N}$ levels $(0,25$, and $50 \mathrm{~kg} \mathrm{~N} /$ fed.) applied in single dose before the first irrigation as ammonium nitrate. All treatments replicated three times. Ten days, after the least irrigation, five plants were taken from each plot for determination of the following growth parameters:

Plant height $(\mathrm{cm})$, No. of tillers / plant, No. of leaves / plant.

Fresh wt. (gm) / plant and Dry wt. (gm) / plant.

At the same time samples of leaves were taken for analysis of N.P and K according to methods of Kock and McMeekin (1924), Troug and Mayers (1939) and Jackson (1967), respectively.

On plot basis and from the successive harvestings, number and weight of pods , were recorded then the following parameters had been calculated; number of pods / plant, yield of pods(gm)/plant, total yield of pods(ton) /fed. Also pod length and diameter $(\mathrm{cm})$ as well as number of seeds/pod were recorded in 20 pods samples collected in mid of harvesting season from each plot.

Finally, all the collected data were statistically analyzed according to (Snedecor and Cochran ,1980).

\section{RESULTS AND DISCUSSION}

\section{1-Vegetative growth :}

\section{1-1-Effect of irrigation frequency :}

Data presented in Table 2 indicate that, increasing irrigations number resulted in significant increments in plant height, number of tillers/plant, fresh and dry weight (gm) / plant of broad bean during the two seasons. The highest watering rate (three irrigations) was the most effective one in maximizing growth potential of such crop.

The results are in agreement with those of (Mehasen, 1998; Soliman et al., 2002; El-Tawill, 2003 and Allam, 2005). 
Table (2): Effect of irrigation frequency on vegetative growth of broad bean plants during two seasons.

\begin{tabular}{ccccccccc}
\hline $\begin{array}{c}\text { Irrigation } \\
\text { frequency } \\
(I)\end{array}$ & \multicolumn{2}{c}{$\begin{array}{c}\text { Plant height } \\
\text { (cm) }\end{array}$} & \multicolumn{2}{c}{$\begin{array}{c}\text { Number of tillers } \\
\text { / plant }\end{array}$} & \multicolumn{2}{c}{$\begin{array}{c}\text { Fresh weight (gm) } \\
\text { /plant }\end{array}$} & \multicolumn{2}{c}{$\begin{array}{c}\text { Dry weight (gm) } \\
\text { /plant }\end{array}$} \\
\cline { 2 - 9 } & $\mathbf{2 0 0 2 -}$ & $\mathbf{2 0 0 3 -}$ & $\mathbf{2 0 0 2 -}$ & $\mathbf{2 0 0 3 -}$ & $\mathbf{2 0 0 2 -}$ & $\mathbf{2 0 0 3 -}$ & $\mathbf{2 0 0 2 -}$ & $\mathbf{2 0 0 3 -}$ \\
\hline One & 156.66 & 152.56 & 17.11 & 15.78 & 1503.67 & 1364.78 & 364.89 & 331.00 \\
Two & 162.22 & 156.11 & 19.33 & 17.11 & 1657.44 & 1516.44 & 402.00 & 356.44 \\
three & 166.22 & 160.33 & 20.11 & 18.44 & 1792.11 & 1653.44 & 426.89 & 370.44 \\
L.S.D(0.05) & 2.15 & 2.85 & 0.828 & 0.91 & 10.15 & 17.3 & 7.5 & 6.25 \\
\hline
\end{tabular}

Herein, the superior effect of increasing the number of irrigations, from single one to three on broad bean growth parameters is logically true, since the same procedure greatly improved the concentration of nitrogen, phosphorus and potassium in plant foliage (Table 5).

This in turn may be enhanced the physiological performance, the efficiency of photoassimilation, the accumulation of dry matter and the whole growth activities.

In addition, Bond et al. (1994) indicated that (Vicia faba L..) plants has a shallow root system with little osmoregulation capacity and that they very sensitive to water stress(deficit), this greatly confirmed the beneficial effect of increasing watering(two and three), explained the least growth values with least watering level (one irrigation).

Also, the results may be explained based on the effect of the suitable watering in enhancing of growth via more cell division and expansion (El-Ganayni, 2000). This also, is in harmony with the finding of Katerji et al.(2006) who, concluded that, broad bean plants had no any mechanism for osmoregulation, stomatal regulation and it is a sensitive crop for water stress, also Abd El-Haleem (1994) indicated that, moisture stress significantly reduced growth capacity of faba bean and that, increasing watering level greatly improved growth and other performances of these plants.

To far extent, the mentioned botanical nature especially for root system and the physiological nature of (Vicia faba L.) plants (Bond et al., 1994) could be explained the best growth performance of broad bean plants that received more than one irrigations.

This may be ensure, sufficient soil moisture, more available water and nutrients uptake during the most critical developmental stages consequently more growth potency.

\section{1-2-Effect of $N$ levels :}

Table 3 illustrated that, all the studied growth characters of broad bean plants were significantly improved along with increasing $\mathrm{N}$ supply from 0 up to $50 \mathrm{~kg} / \mathrm{fed}$., during the two seasons. 
Table 3: Effect of nitrogen levels on vegetative growth of broad bean plants during two seasons.

\begin{tabular}{|c|c|c|c|c|c|c|c|c|}
\hline \multirow{2}{*}{$\begin{array}{c}\text { Nitrogen } \\
\text { levels } \\
\text { (N) }\end{array}$} & \multicolumn{2}{|c|}{$\begin{array}{l}\text { Plant height } \\
\text { (cm) }\end{array}$} & \multicolumn{2}{|c|}{$\begin{array}{l}\text { Number of } \\
\text { tillers / plant }\end{array}$} & \multicolumn{2}{|c|}{$\begin{array}{l}\text { Fresh weight } \\
\text { (gm)/plant }\end{array}$} & \multicolumn{2}{|c|}{$\begin{array}{l}\text { Dry weight } \\
\text { (gm)/plant }\end{array}$} \\
\hline & $\begin{array}{l}2002- \\
2003\end{array}$ & $\begin{array}{l}2003- \\
2004 \\
\end{array}$ & $\begin{array}{l}2002- \\
2003\end{array}$ & $\begin{array}{l}2003- \\
2004\end{array}$ & $\begin{array}{l}2002- \\
2003\end{array}$ & $\begin{array}{r}2003- \\
2004 \\
\end{array}$ & $\begin{array}{l}2002- \\
2003\end{array}$ & $\begin{array}{l}2003- \\
2004 \\
\end{array}$ \\
\hline $\begin{array}{c}\mathbf{0} \\
(\text { Zero) }\end{array}$ & 151.22 & 146.56 & 15.67 & 14.48 & 1324.89 & 1191.78 & 319.22 & 277.89 \\
\hline $\begin{array}{c}25 \mathrm{~kg} \\
\text { N/fed. }\end{array}$ & 162.33 & 157.44 & 18.56 & 16.67 & 1638.89 & 1498.44 & 395.11 & 343.89 \\
\hline $\begin{array}{l}50 \mathrm{~kg} \\
\text { N/fed. }\end{array}$ & 171.56 & 165.00 & 22.33 & 19.89 & 1989.44 & 1844.44 & 479.44 & 436.11 \\
\hline L.S.D (0.05) & 1.44 & 2.54 & 0.558 & 0.48 & 13.75 & 16.75 & 7.17 & 4.32 \\
\hline
\end{tabular}

Obviously, the plants which received no $\mathrm{N}$ application had the least capacity of growth in term of length and tillering and of biomass (fresh and dry weight) synthesis. Such growth case was greatly improved by the application of $25 \mathrm{~kg} / \mathrm{N} /$ fed. maximized as a result of increasing the applied $\mathrm{N}$ to $50 \mathrm{~kg} /$ fed. The marked growth response of broad bean plants to the increasingly $\mathrm{N}$ supply is greatly confirm the view of its need for $\mathrm{N}$ fertilization over its own potential for $\mathrm{N}$ fixation. This may be to ensure sufficient supply required for its potential growth habit, strong tillering and multiplying harvesting of pods, compared with other legume plants.

In early research works, Bhan- Goo and Albritton (1972) found that, $112 \mathrm{~kg}$ $\mathrm{N} / \mathrm{ha}$. is sufficient to improve growth and increase yield of soya bean by $10-15 \%$.

In this connection, Bond et al.(1994) regarded field grown faba bean as a crop need no $\mathrm{N}$ fertilization to attain better growth and high yield. Papendick et al.(1988) stated that, even with apparently satisfactory nodulation, it could obtain considerable growth and yield responses to $\mathrm{N}$ application.

Other research work proved that, faba bean is required $\mathrm{N}$ fertilization for maximum growth and productivity, this found to be ranged from applying small $\mathrm{N}$ starter dressing to large ones (Said, 1998).

Herein the superior growth performance of broad bean plants, as a result of applying the highest $\mathrm{N}$ rate $(50 \mathrm{~kg} \mathrm{~N} /$ fed.) compared with others could be due to its similar beneficial effect on the concentration of $\mathrm{N}, \mathrm{P}$ and $\mathrm{K}$ in its plants foliage (Table 6)

\section{1-3-Effect of interaction :}

From Table 4 it was clear that, along with increasing number of irrigations during the critical periods of broad bean plants development, increasing rates of the applied nitrogen greatly improved all the studied parameters of growth during the two seasons.

Also, it was obvious that, the treatment of three irrigations with the highest rate of $\mathrm{N}$ fertilization $(50 \mathrm{~kg} / \mathrm{fed}$.) followed by this of two irrigations with the highest $\mathrm{N}$ rate too were the best ones and resulted in considerable increase in fresh and dry weight relative to other interaction treatments in both seasons. 
Table 4 : Effect of interaction between irrigation frequency and nitrogen levels on vegetative growth of broad bean plants during two seasons.

\begin{tabular}{|c|c|c|c|c|c|c|c|c|c|}
\hline \multirow{2}{*}{\multicolumn{2}{|c|}{$\begin{array}{c}\text { Interactio } \\
\mathbf{n} \\
\mathbf{I} \times \mathbf{~} \mathbf{N}\end{array}$}} & \multicolumn{2}{|c|}{$\begin{array}{l}\text { Plant height } \\
(\mathrm{cm})\end{array}$} & \multicolumn{2}{|c|}{$\begin{array}{c}\text { Number of } \\
\text { tillers / plant }\end{array}$} & \multicolumn{2}{|c|}{$\begin{array}{c}\text { Fresh weight } \\
(\mathrm{gm}) / \text { plant }\end{array}$} & \multicolumn{2}{|c|}{$\begin{array}{c}\text { Dry weight } \\
\text { (gm)/plant }\end{array}$} \\
\hline & & $\begin{array}{l}2002- \\
2003\end{array}$ & $\begin{array}{l}2003- \\
2004\end{array}$ & $\begin{array}{c}2002 \\
- \\
2003\end{array}$ & $\begin{array}{l}2003- \\
2004\end{array}$ & $\begin{array}{l}2002- \\
2003\end{array}$ & $\begin{array}{l}2003- \\
2004\end{array}$ & $\begin{array}{l}2002- \\
2003\end{array}$ & $\begin{array}{c}2003- \\
2004\end{array}$ \\
\hline \multirow{3}{*}{ One } & 0 & 145.33 & 141.67 & 14.00 & 13.67 & 1207.33 & 1075.00 & 290.33 & 256.67 \\
\hline & 25 & 157.00 & 154.00 & 16.33 & 15.33 & 1422.67 & 1277.33 & 345.67 & 304.67 \\
\hline & 50 & 167.67 & 162.00 & 21.00 & 18.33 & 1881.00 & 1742.00 & 458.67 & 431.67 \\
\hline \multirow{3}{*}{ Two } & 0 & 151.33 & 146.67 & 15.67 & 15.00 & 1351.67 & 1214.33 & 324.33 & 286.67 \\
\hline & 25 & 163.00 & 157.00 & 19.33 & 16.33 & 1620.00 & 1485.33 & 396.33 & 347.00 \\
\hline & 50 & 172.00 & 164.67 & 23.00 & 20.00 & 2000.67 & 1849.67 & 485.33 & 435.67 \\
\hline \multirow{3}{*}{ Three } & 0 & 157.00 & 151.33 & 17.33 & 15.67 & 1415.67 & 1286.00 & 343.00 & 290.33 \\
\hline & 25 & 167.00 & 161.33 & 20.00 & 18.33 & 1874.00 & 1732.67 & 443.33 & 380.00 \\
\hline & 50 & 174.00 & 168.33 & 23.00 & 21.33 & 2086.67 & 1941.67 & 494.33 & 441.00 \\
\hline \multicolumn{2}{|c|}{ L.S.D (0.05) } & 2.49 & 4.4 & 0.97 & 0.84 & 23.81 & 29.01 & 12.4 & 7.48 \\
\hline
\end{tabular}

The same results revealed that, other interaction treatments, i.e. one irrigation and three irrigations with the highest $\mathrm{N}$ level (50 kg N / fed.) and (25 kg N / fed.) respectively were also of beneficial improvement effect on tillering and biomass accumulation of their plants with less differences between them in most cases.

In contrary, the absolute worst growth performance was of no $\mathrm{N}$ fertilization with one irrigation treatment in the two seasons.

Herein, the present results of interaction treatments could be explained based on their similar effect on the concentration of N, P and $\mathrm{K}$ in the foliage parts of their plants (Table 7) and in turn the physiological and metabolical case which extended to their growth behavior.

These results of interaction were in line and confirmed by those of (Buchner and Sturm, 1971) who pointed out that, increasing soil moisture content, maximized the yield responses to increasing N supply. Also, Mengel and Casper (1980) stated that, low levels of watering and soil moisture reduced NO3 availability and $\mathrm{N}$ metabolism efficiency.

\section{2-Mineral composition :}

\section{2-1-Effect of irrigation frequency :}

Table 5 illustrated that, increasing irrigation frequency from single to three ones is considerably increased concentration of $\mathrm{N}, \mathrm{P}$ and $\mathrm{K}$ within leaves. This data also proved that, only the differences in $\mathrm{K}$ concentration between two and three irrigations are not at the satisfactory level in the two seasons. 
Table (5): Effect of irrigation frequency on mineral composition of broad bean plants during two seasons.

\begin{tabular}{ccccccc}
\hline Irrigation & \multicolumn{2}{c}{ N \% } & \multicolumn{2}{c}{ P \% } & \multicolumn{2}{c}{ K \% } \\
\cline { 2 - 7 } frequency (I) & $\mathbf{2 0 0 2 -}$ & $\mathbf{2 0 0 3 -}$ & $\mathbf{2 0 0 2 -}$ & $\mathbf{2 0 0 3 -}$ & $\mathbf{2 0 0 2 -}$ & $\mathbf{2 0 0 3 -}$ \\
& $\mathbf{2 0 0 3}$ & $\mathbf{2 0 0 4}$ & $\mathbf{2 0 0 3}$ & $\mathbf{2 0 0 4}$ & $\mathbf{2 0 0 3}$ & $\mathbf{2 0 0 4}$ \\
\hline One & 2.24 & 2.20 & 0.181 & 0.176 & 2.66 & 2.59 \\
Two & 2.35 & 2.27 & 0.196 & 0.192 & 2.85 & 2.70 \\
three & 2.45 & 2.34 & 0.202 & 0.196 & 2.88 & 2.78 \\
\hline L.S.D $(\mathbf{0 . 0 5})$ & 0.032 & 0.073 & 0.01 & 0.01 & 0.046 & 0.045 \\
\hline
\end{tabular}

The beneficial effect of watering on the concentration of minerals within plant leaves was confirmed by the results of Abd El-Haleem (1994) and El-Tawill (2003).

\section{2-2-Effect of $N$ levels :}

Increasing the applied $\mathrm{N}$ from 0 up to $50 \mathrm{~kg} / \mathrm{fed}$. resulted in significant increments in N,P and K concentration of broad bean leaves during the two seasons Table 6. Similar findings were obtained by Said (1998).

Table (6): Effect of nitrogen levels on mineral composition of broad bean plants during two seasons.

\begin{tabular}{ccccccc}
\hline Nitrogen & \multicolumn{2}{c}{ N \% } & \multicolumn{2}{c}{ P \% } & \multicolumn{2}{c}{ K \% } \\
\cline { 2 - 7 } levels & $\mathbf{2 0 0 2 -}$ & $\mathbf{2 0 0 3 -}$ & $\mathbf{2 0 0 2 -}$ & $\mathbf{2 0 0 3 -}$ & $\mathbf{2 0 0 2 -}$ & $\mathbf{2 0 0 3 -}$ \\
(N) & $\mathbf{2 0 0 3}$ & $\mathbf{2 0 0 4}$ & $\mathbf{2 0 0 3}$ & $\mathbf{2 0 0 4}$ & $\mathbf{2 0 0 3}$ & $\mathbf{2 0 0 4}$ \\
\hline 0 (Zero) & 1.73 & 1.65 & 0.144 & 0.138 & 2.47 & 2.41 \\
$\mathbf{2 5}$ kg N/fed. & 2.50 & 2.45 & 0.209 & 0.205 & 2.77 & 2.65 \\
$\mathbf{5 0}$ kg N/fed. & 2.81 & 2.71 & 0.226 & 0.221 & 3.14 & 3.01 \\
\hline L.S.D (0.05) & 0.01 & 0.056 & 0.01 & 0.012 & 0.045 & 0.056 \\
\hline
\end{tabular}

\section{2-3-Effect of interaction :}

It was illustrated in Table 7 that, along with increasing watering frequency, increasing rate of $\mathrm{N}$ fertilizer from 0 up to $50 \mathrm{~kg} / \mathrm{fed}$. increased significantly the concentration of N,P and $\mathrm{K}$ within broad bean leaves during the two seasons. The same data proved that, the highest $\mathrm{N}$ and $\mathrm{P}$ concentrations was established by the highest $\mathrm{N}$ rate with any watering frequency, one, two and three with less or no considerable differences among them in the two seasons.

Meanwhile, the highest concentration of $\mathrm{K}$ was of two and three irrigations with the highest $\mathrm{N}$ rate without significant differences between them followed by that of one watering with $50 \mathrm{~kg} \mathrm{~N} / \mathrm{fed}$., three watering application with $25 \mathrm{~kg} \mathrm{~N} / \mathrm{fed}$. and two watering with $25 \mathrm{~kg} \mathrm{~N} /$ fed. respectively during both seasons. 
Table (7): Effect of interaction between irrigation frequency and nitrogen levels on mineral composition of broad bean plants during two seasons.

\begin{tabular}{|c|c|c|c|c|c|c|c|}
\hline \multirow{2}{*}{\multicolumn{2}{|c|}{$\begin{array}{c}\text { Interaction } \\
\text { I x N }\end{array}$}} & \multicolumn{2}{|c|}{$\mathrm{N} \%$} & \multicolumn{2}{|c|}{ P \% } & \multicolumn{2}{|c|}{ K \% } \\
\hline & & $\begin{array}{c}2002- \\
2003\end{array}$ & $\begin{array}{l}2003- \\
2004\end{array}$ & $\begin{array}{l}2002- \\
2003\end{array}$ & $\begin{array}{l}2003- \\
2004\end{array}$ & $\begin{array}{r}2002- \\
2003\end{array}$ & $\begin{array}{l}2003- \\
2004\end{array}$ \\
\hline \multirow{3}{*}{ One } & $\mathbf{0}$ & 1.63 & 1.53 & 0.137 & 0.130 & 2.40 & 2.34 \\
\hline & 25 & 2.38 & 2.32 & 0.192 & 0.189 & 2.62 & 2.47 \\
\hline & 50 & 2.72 & 2.75 & 0.215 & 0.210 & 2.97 & 2.95 \\
\hline \multirow{3}{*}{ Two } & 0 & 1.72 & 1.66 & 0.142 & 0.137 & 2.47 & 2.39 \\
\hline & 25 & 2.50 & 2.49 & 0.210 & 0.212 & 2.82 & 2.67 \\
\hline & 50 & 2.81 & 2.66 & 0.235 & 0.230 & 3.25 & 3.05 \\
\hline \multirow{3}{*}{ Three } & $\mathbf{0}$ & 1.82 & 1.76 & 0.153 & 0.148 & 2.54 & 2.48 \\
\hline & 25 & 2.61 & 2.53 & 0.224 & 0.215 & 2.89 & 2.81 \\
\hline & 50 & 2.90 & 2.72 & 0.228 & 0.224 & 3.21 & 3.03 \\
\hline \multicolumn{2}{|c|}{ L.S.D (0.05) } & 0.18 & 0.097 & 0.018 & 0.018 & 0.08 & 0.097 \\
\hline
\end{tabular}

3-Yield and its components :

\section{3-1-Effect of irrigation frequency :}

Data in Table 8 indicate that, increasing number of irrigations considerably increased number of pod /plant, two and three irrigations greatly superiored one irrigation with significant differences among them in the two seasons. In this case, one irrigation procedure after planting irrigation may be established no adequate and shortage soil moisture case, stressed the plants, reduced their tillering capacity (Table 2), reduced their mineral concentration (Table 5), induced many physiological and biochemical disturbances(Abd El-Haleem, 1994). This case may be dramatically extended to and interfere with the critical stages of flowering and pod formation stages, reduced pods setting and retention ability.

Meanwhile, the reverse is true for the plants of two and three irrigations, those which suggest to be provided sufficient soil moisture content during the critical and whole growing season periods. It was clear also that, number of seeds/pod increased but not significantly with increasing number of irrigations during the two seasons. The same data revealed that, pod length is not significantly affected by watering treatments. Whilst, pod diameter is significantly increased with two and three irrigations (with no considerable differences among them) compared with one watering treatment in both seasons. It was also evident from Table 8 that, increasing watering over one irrigation is greatly increased pod yield /plant and total yield /fed. but there are no significant differences between two and three irrigations.

These results take the same trend in both seasons. Also, were in line with those obtained by ( El-Tawill, 2003; Allam, 2005 ; Linsalata et al., 2006; Linsalata and Bianco, 2006). Herein the enhancable effect of increasing watering frequency on broad bean pod yields can be attribute with the similar advantageous effect of the same watering procedure on number of tillers and the accumulated biomass (Table 2 ), concentration of minerals (Table 5), added to number of pods. 
From the whole performances of broad bean (Tables 2, 5 and 8) in response to watering treatments. It could be suggest that, it is a sensitive crop to water and soil moisture shortage, the most critical periods is extended during flowering, pod setting and formation.

Also that, application of two irrigations (one just before flowering and at the beginning of pod formation besides to sowing irrigation is efficient watering procedure to ensure sufficient soil moisture status during the most physiologically critical stages and the whole periods of flowering, pod formation and extended to pod filling stage, this for better growth and mineral concentration corresponded with maximum productivity.

\section{3-2-Effect of nitrogen levels :}

Data in Table 9 show that, along with increasing rate of the applied $\mathrm{N}$ from 0 up to $50 \mathrm{~kg} / \mathrm{fed}$. significantly increased number of pods /plant, number of seeds /pod, length and diameter of pods, yield of pods /plant and /fed.

The results were in similar trend during the two seasons. Also could be explained based on the same beneficial effect of the applied $\mathrm{N}$ on growth potential and mineral concentration Tables ( 3 and 6).

The results were in line with those of (Hammam,1995, Said,1998;) and contradicted with those of Bond et al.,(1994) who regarded Vicia faba L., plants as a crop need no $\mathrm{N}$ fertilization to attain high yield responses.

This also, in consistent with Papendick et al. (1988) who stated that, even with apparently satisfactory nodulation, it could obtain considerable yield responses to $\mathrm{N}$ application.

\section{3-3-Effect of interaction :}

Data in Table 10 illustrated that, interaction treatments were significantly improved broad bean yield and its components during the two seasons of this work.

The same data proved that the most effective ones of the significant highest yield values were two irrigations followed by three irrigations both with highest $\mathrm{N}$ rate $(50 \mathrm{~kg} / \mathrm{fed}$.) with less differences between them in most cases except this for pod yield /plant in the two years.

Whilst, the least components and yields were of one irrigation with no $\mathrm{N}$ fertilization in the two seasons.

Finally, the results of this work is greatly emphasized the importance of inorganic $\mathrm{N}$ application (50 kg / fed.) along with two watering applied before flowering and at the beginning of pod formation, all to optimize broad bean growth and mineral concentration of its foliage and maximize its pod productivity. 


\section{REFERENCE}

Abd El-Haleem, A.K.(1994). Growth and yield of faba bean as affected by inoculation phosphorus fertilization and irrigation frequency. J Agric. Sci., Mansoura Univ., 19 (11) :3563-3574.

Abo El-Kheir, M. S. A.; A. A. Abo-Ellil and H. A. El-Zeiny (2000). Effect of water stress at different growth stages on three faba bean cultivars.J.Agric.Sci.Mansoura Univ., 25 (3): 1485-1493.

Allam, S. A. (2005). Faba bean potentialities as affected by irrigation and potassium fertilization treatments. J. Agric. Sci., Mansoura Univ., 30(4): 1861-1869.

Bhan-Goo, M.S. and Albritton(1972): Effect of fertilizer nitrogen, phosphorus, and potassium on yield and nutrient content of Lee soybeans. Agron. J., 64: 743746.

Bond, D.A.; G.J. Jellis; G.G. Rowland; J. Le-Guen; L.D. Robertson; S.A. Khalil, and L.Li-Juan. (1994). Present status and future strategy in breeding faba bean (Vicia faba L.) for resistance to biotic abiotic stress.Euphytica, 73:151166. \{ISI\}.

Buchner, A.and Sturm, H.(1971): (G) Fertilizer Application in Intensive Agriculture, $3^{\text {rd }}$ ed. ,DLG-Verlag, Frankfurt / Main., pp156.

El-Ganayni, A. A.(2000). Scheduling irrigation using Pan evaporation under some potassium levels in (Vicia faba L.). J. Agric. Sci. Mansoura, 25 (3) :15231538

El-Tawill, A.Y.(2003). Effect of irrigation intervals and some nutrients application on broad bean production, nutrients uptakes and some water relations in different soil. J. Agric. Sci. Mansoura Univ.,28 (4) :3227-3245.

Hammam, G. Y.(1995). Faba bean (Vicia faba L.) response to inoculation and N, P and K fertilizers. J. Agric. Sci. Mansoura Univ., 20 (2):609-616.

Jackson,M.L.(1967). Soil Chemical Analysis. Prentice Hall of India Private Limited, New Delhi.

Katerji,K.;M.Mastrorilli;A.Hamdy;T.W.Van Hoorn(2006). Water status and osmotic adjustment of broad bean (Vicia faba L.) in response to soil salinity. \{Ishs\} acta Hort. 573: International Symposium on Tech. to Control Salination for Hortcultural Productivity.

Kock, F.C. and T.L. Mc Meekin (1824). Chemical analysis of food and food products. J. Amer. Chem. Soc.,46: 2066

Linsalate, D. and Bianco, V.V.(2006).Effects of time of sowing and water regime on seed yield of broad beans. ISHS, Acta Hort., 111: Symposium on Vegetable and Flower Seed Production.

Linsalate, D.; B. Spada and V.V. Bianco (2006). Climate and water regimes on broad bean for green consumption. \{ISHS \}Acta Hort., 278: Symposium on Scheduling of Irrigation for Vegetable Crops under Field Condition.

Mehasen, S.A.S.(1998). Response of some new pure lines of faba bean to irrigation treatments. Annals of Agric.Sci., Moshtohor, 36(4):2063-2070. 
Mengel, K.and Casper, H.:(1980). The effect of soil moisture on the availability of soil nitrate. Pflanzenernahr, Bodenkd., 143: 617-626.

Papendick, R.I.; S.L. Chowdhury, and C. Johansen. (1988). Managing systems for increasing productivity of pulses in dryland agriculture.P.237-255. In.R.J. Dummerfield(ed.) World crops: Cool Season Food Legumes. Kluwer Academic Pupl., Dordrecht, the Netherlands.

Said, E.M.(1998). Response of some faba bean (Vicia faba,L.)varieties to phosphorus and starter doses from nitrogen fertilization. J. Agric. Sci., Mansoura Univ., 23(6):2369-2377.

Snedecor, G. W. and W. G. Cochran (1980). Statistical Methods. $7^{\text {th }}$ ed. Lowa State Univ. ,Press Lowa, USA.

Soliman, Mona A. M. and Salwa E. Soliman (2002). Effect of amount of dripped water on seed yield and its components and their relative contribution and correlation in two faba bean (Vicia faba,L.) cultivars. J. Agric. Sci. Mansoura Univ.,27 (4): 2027-2039.

Troug, E.and A.H.Mayers (1939). Improvement in the denies colorimetric method for phosphorus and arsenic.Ind.Eng.Chem.Anal.Ed.,1:136-139. 


\title{
تأثير الري ومستويات الأزوت على النمو والتركيب الكيماوي والمحصول للفول الرومي
}

\author{
السعيد لطفي السيد *- محمود محمد الحمادى **- السعيد محمود السعيد فتحى* \\ * قسم بحوث الخضر - معهد بحوث البساتين - مركز البحوث الزر اعيةـ الجيزة- مصر.

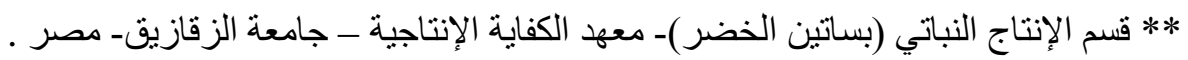

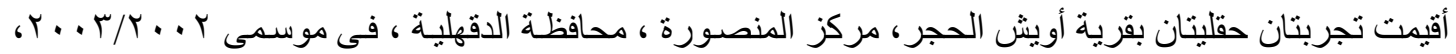

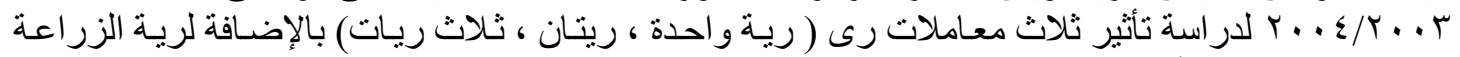

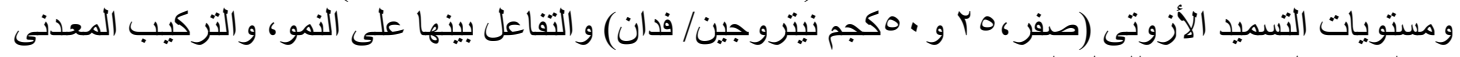

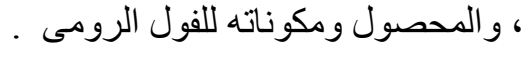

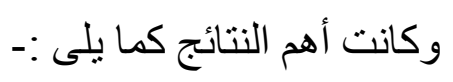

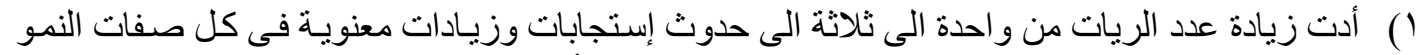

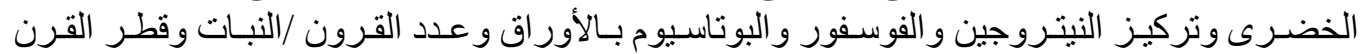

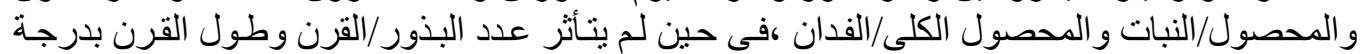

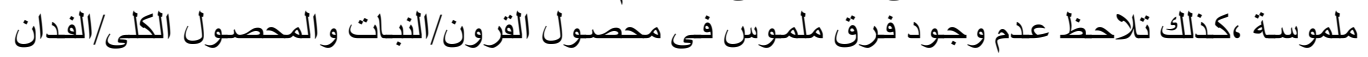

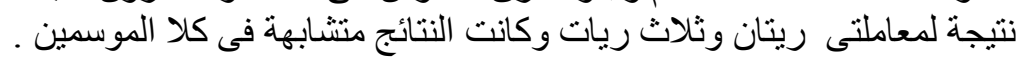

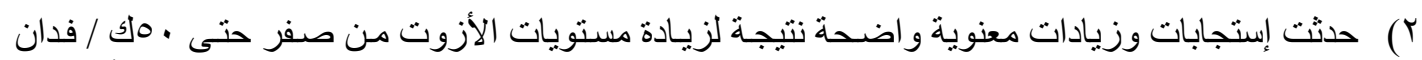

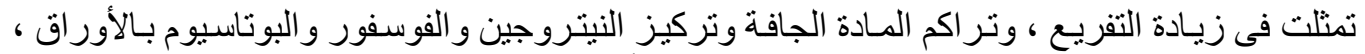

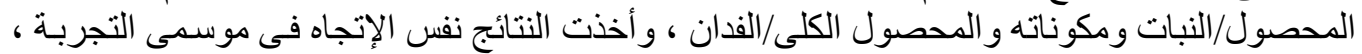

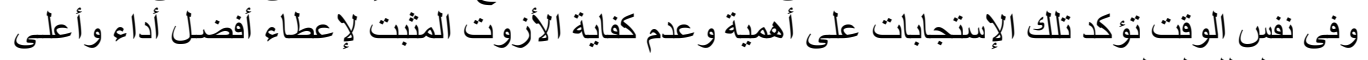

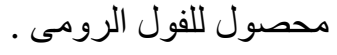

r) أعطى التفاعل تأثثرات معنويـة مفيدة على النمو و التركيب المعدنى و المحصول ومكوناته فى موسمى التجربة . التجاعل

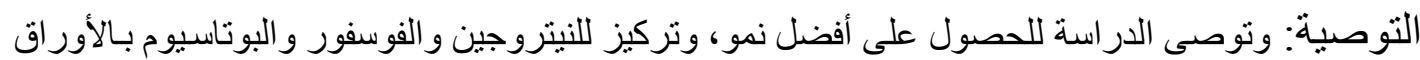

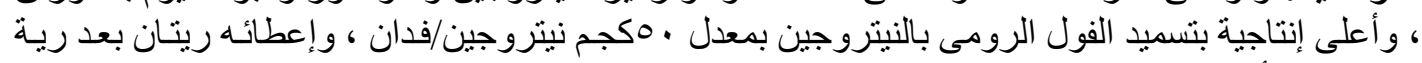

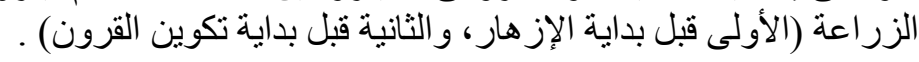

